\title{
Assessing inflammatory bowel disease-associated antibodies in Caucasian and First Nations cohorts
}

\author{
Charles $\mathrm{N}$ Bernstein $\mathrm{MD}^{1,2}$, Hani El-Gabalawy MD², Michael Sargent ${ }^{1,2}$, Carol J Landers PhD ${ }^{4}$, \\ Patricia Rawsthorne $\mathrm{RN}^{1,2}$, Brenda Elias $\mathrm{PhD}^{3}$, Stephan R Targan $\mathrm{MD}^{4}$
}

\begin{abstract}
CN Bernstein, H El-Gabalawy, M Sargent, et al. Assessing inflammatory bowel disease-associated antibodies in Caucasian and First Nations cohorts. Can J Gastroenterol 2011;25(5):
\end{abstract} 269-273.

BACKGROUND: First Nation populations in Canada have a very low incidence of inflammatory bowel disease (IBD). Based on typical infections in this population, it is plausible that the First Nations react differently to microbial antigens with a different antibody response pattern, which may shed some light as to why they experience a low rate of IBD.

OBJECTIVE: To compare the positivity rates of antibodies known to be associated with IBD in Canadian First Nations compared with a Canadian Caucasian population.

METHODS: Subjects with Crohn's disease, ulcerative colitis (UC), rheumatoid arthritis (RA) (as an immune disease control) and healthy controls without a personal or family history of chronic immune diseases, were enrolled in a cohort study aimed to determine differences between First Nations and Caucasians with IBD or RA. Serum from a random sample of these subjects ( $\mathrm{n}=50$ for each of First Nations with RA, First Nations controls, Caucasians with RA, Caucasians with Crohn's disease, Caucasians with UC and Caucasians controls, and as many First Nations with either Crohn's disease or UC as could be enrolled) was analyzed in the laboratory for the following antibodies: perinuclear antineutrophil cytoplasmic antibody (pANCA), and four Crohn's disease-associated antibodies including anti-Saccharomyces cerevisiae, the outer membrane porin $\mathrm{C}$ of Escherichia coli, I2 - a fragment of bacterial DNA associated with Pseudomonas fluorescens, and the bacterial flagellin CBir-1. The rates of positive antibody responses and mean titres among positive results were compared.

RESULTS: For pANCA, First Nations had a positivity rate of $55 \%$ in those with UC, $32 \%$ in healthy controls and $48 \%$ in those with RA. The pANCA positivity rate was $32 \%$ among Caucasians with RA. The rates of the Crohn's disease-associated antibodies for the First Nations and Caucasians were comparable. Among First Nations, up to one in four healthy controls were positive for any one of the Crohn's disease-associated antibodies. First Nations had significantly higher pANCA titres in both the UC and RA groups than Caucasians

DISCUSSION: Although First Nation populations experience a low rate of IBD, they are relatively responsive to this particular antibody panel. CONCLUSIONS: The positivity rates of these antibodies in First Nations, despite the low incidence of IBD in this population, suggest that these antibodies are unlikely to be of pathogenetic significance.

Key Words: Antibodies; Crohn's disease; Ethnicity; Inflammatory bowel disease; Rheumatoid arthritis; Ulcerative colitis

Inflammatory bowel disease (IBD) affects approximately $0.5 \%$ 1 (approximately 200,000) of Canadians (1). We previously reported on the epidemiology of IBD in Manitoba (2) and across five provinces (1) using population-based administrative data. While the rates in Canada are among the highest in the world $(1,3,4)$, the rates in British Columbia, particularly for Crohn's disease, are much lower than elsewhere in Canada $(1,3)$. One potential explanation for this difference in British Columbia is that nearly $25 \%$ of the population are visible minorities, of which many are Asian immigrants, thereby underscoring the importance of exploring these diseases in different ethnic/ancestral

\section{L'évaluation des anticorps liés aux MII chez des cohortes de blancs et des Premières nations}

HISTORIQUE : Les populations des Premières nations du Canada présentent une très faible incidence de maladies inflammatoires de l'intestin (MII). D'après les infections classiques au sein de cette population, il est possible que les Premières nations réagissent différemment aux antigènes microbiens ayant un mode de réponse anticorps différent, ce qui pourrait jeter la lumière sur les raisons de leur taux peu élevé de MII.

OBJECTIF : Comparer les taux de positivité des anticorps qu'on sait associés aux MII au sein de Premières nations du Canada à ceux d'une population blanche du Canada.

MÉTHODOLOGIE : Les sujets atteints de maladie de Crohn, de colite ulcéreuse (CU), de polyarthrite rhumatoïde (PR) (une maladie immunitaire témoin) et des sujets témoins en santé sans antécédents personnels ou familiaux de maladie immunitaire chronique ont participé à une étude de cohorte visant à déterminer les différences entre les Premières nations et les blancs atteints d'une MII ou de PA. Les chercheurs ont analysé en laboratoire le sérum d'un échantillon aléatoire de ces sujets ( $\mathrm{n}=50$ pour chacun des membres des Premières nations atteints de $\mathrm{PR}$, des sujets témoins des Premières nations, des blancs atteints de PR, des blancs atteints de maladie de Crohn, des blancs atteints de CU et de sujets témoins blancs, et autant de membres des Premières nations atteints de maladie de Crohn ou de CU qu'on pouvait inscrire) afin d'y déceler les anticorps suivants : anticorps antineutrophiles cytoplasmatiques des polynucléaires (AANCp) et quatre anticorps liés à la maladie de Crohn, y compris l'anti-Saccharomyces cerevisiae, la membrane externe de la porine C de l'Escherichia coli, I2 - un fragment d'ADN bactérien associé au Pseudomonas fluorescens - et la flagelline bactérienne CBir-1. Les chercheurs ont comparé les taux de réponses anticorps positives et les titres moyens parmi les résultats positifs.

RÉSULTATS : Pour ce qui est des AANCp, les Premières nations avaient un taux de positivité de $55 \%$ s'ils étaient atteints de CU, de $32 \%$ s'ils étaient des sujets témoins et de $48 \%$ s'ils étaient atteints de PR. Le taux de positivité aux AANCp s'élevait à $32 \%$ chez les blancs atteints de PR. Les taux d'anticorps associés à la maladie de Crohn étaient comparables chez les membres des Premières nations et les blancs. Chez les membres des Premières nations, jusqu'à un sujet témoin en santé sur quatre était positif à l'un des anticorps associés à la maladie de Crohn. Les titres d'AANCp étaient considérablement plus élevés dans les groupes des Premières nations atteints de $\mathrm{CU}$ ou de PR que chez les blancs.

EXPOSÉ : Même si les populations des Premières nations présentent un faible taux de MII, ils sont relativement réactifs à ce groupe précis d'anticorps.

CONCLUSIONS : Les taux de positivité de ces anticorps au sein des Premières nations, malgré la faible incidence de MII dans cette population, indique que ces anticorps sont peu susceptibles d'avoir une signification pathogène.

groups. In Manitoba, we previously reported the markedly lower rates of IBD among First Nations (FN) people compared with Caucasians $(5,6)$ by a factor of 3 to 4 in ulcerative colitis and by a factor of 10 to 12 for Crohn's disease. The fourfold increased rates of ulcerative colitis versus Crohn's disease among the FN are consistent with the greater rates of ulcerative colitis in emerging nations compared with Crohn's disease, with the reverse being the case among most contemporary western nations including the Caucasian community of Canada (7). Approximately $10 \%$ of Manitobans are FN, and approximately one- half live in the city of Winnipeg while one-half live in rural communities.

${ }^{1}$ IBD Clinical Eु Research Centre; ${ }^{2}$ Department of Internal Medicine; ${ }^{3}$ Department of Community Health Sciences, University of Manitoba, Winnipeg,

Manitoba; ${ }^{4}$ Cedars Sinai Medical Center, Los Angeles, California, USA

Correspondence: Dr Charles N Bernstein, IBD Clinical E⿱ Research Centre, University of Manitoba, 804F-715 McDermot Avenue, Winnipeg,

Manitoba R3E 3P4. Telephone 204-789-3369, fax 204-789-3972, e-mail cbernst@cc.umanitoba.ca

Received for publication September 14, 2010. Accepted October 13, 2010 
TABLE 1

\section{Study population}

\begin{tabular}{lcc}
\hline & Females, \% & Age, years (mean) \\
\hline CD, Caucasian $(n=50)$ & 50 & 39.9 \\
CD, First Nations $(n=9)$ & 67 & 35 \\
UC, Caucasian $(n=50)$ & 50 & 39 \\
UC, First Nations $(n=11)$ & 55 & 46 \\
RA, Caucasian $(n=50)$ & 84 & 59.7 \\
RA, First Nations $(n=50)$ & 78 & 46.7 \\
Controls, Caucasian $(n=50)$ & 77 & 41.7 \\
Controls, First Nations $(n=50)$ & 57 & 34.5 \\
\hline
\end{tabular}

$C D$ Crohn's disease; RA Rheumatoid arthritis; UC Ulcerative colitis

The lower rates of IBD are similarly evident among both urban and rural FN. The lower rate of IBD in the FN population does not reflect a general reduction in autoimmune disease in this ethnic/ancestral group - they have a significantly increased prevalence of rheumatoid arthritis (RA) compared with Caucasians (8-16). Using Manitoba Health administrative data, Manitoba registered FN were found to have an RA prevalence rate of $2 \%$ - twice that of the surrounding, predominantly Caucasian population (17).

Hence, it is important to study communities with discrepant rates of disease to investigate whether there are genetic or environmental etiological clues. The present study was one aspect of a larger cohort study in which Manitobans with either Crohn's disease, ulcerative colitis or RA, or were healthy controls without any autoimmune diseases and without first-degree relatives with autoimmune diseases were enrolled. We included persons who were either Caucasian or FN (Canadian Institutes of Health Research Team Grant in Arthritis and IBD). We took a random sample of these subjects and explored their responsiveness to a panel of antibodies associated with IBD. These antibodies are used diagnostically and may have prognostic roles; however, it is unclear whether they play any pathogenetic roles.

Increasingly, there is enthusiasm for the prospect that gut dysbiosis is central to the initiation of either form of IBD and that some bacterial species may be trigger(s) $(18,19)$. Hence, antibodies to microbial antigens may represent an adaptive immune response that has more relevance than merely serving as a biomarker. An exploration of the antibody responses in FN populations - who generally have a low incidence of IBD - could help clarify the importance of these antibodies in pathogenesis. Furthermore, we determined the diagnostic utility of these antibodies in an FN population.

\section{METHODS}

\section{Subjects}

The Canadian Institutes of Health Research Team Grant in Arthritis and IBD specifically enrolled a cohort of Caucasian or FN Manitobans with Crohn's disease, ulcerative colitis or RA, and healthy controls (without any autoimmune disease or first-degree relatives with autoimmune disease). Persons of mixed race were excluded to minimize issues related to admixture. Consecutive subjects with IBD and RA meeting enrollment criteria presenting to the University of Manitoba Health Sciences Centre (Winnipeg, Manitoba) specialty clinics of two of the principal investigators (CNB and HEG), as well as RA patients living in FN communities where one principal investigator (HEG) holds clinics, were invited to enrol. Healthy controls of Caucasian and FN descent who answered advertisements posted at the University of Manitoba Health Science Centre specialty clinics and in the clinics of the participating FN communities were also invited to participate. Blood was drawn for serum and DNA extraction to determine differential expression of biomarkers and genes of Caucasians and FN (exploration of differences in genotype between the disease groups and among the different racial groups is underway). A random sample $(n=50)$ of each category of enrollee was taken. The only exception was for FN with Crohn's disease $(n=9)$ and FN with ulcerative colitis $(n=11)$ due to a lack of subjects in those categories.
TABLE 2

Antibody results

\begin{tabular}{lcrrrrrrr}
\hline & & \multicolumn{3}{c}{ ASCA } & & \\
\cline { 3 - 6 } & pANCA & IgA & IgG & Panel* $^{*}$ & I2 & Omp-C CBir-1 \\
\hline CD, Caucasian & 10 & 50 & 62 & 66 & 14 & 24 & 38 \\
CD, First Nations & 33 & 33 & 22 & 33 & 0 & 22 & 22 \\
UC, Caucasian & 46 & 4 & 12 & 14 & 4 & 10 & 12 \\
UC, First Nations & 55 & 9 & 18 & 18 & 0 & 9 & 27 \\
RA, Caucasian & 32 & 2 & 4 & 8 & 2 & 18 & 2 \\
RA, First Nations & 48 & 2 & 10 & 10 & 8 & 18 & 4 \\
Controls, Caucasian & 16 & 6 & 16 & 18 & 2 & 4 & 2 \\
Controls, First Nations & 32 & 4 & 12 & 14 & 8 & 6 & 2 \\
\hline
\end{tabular}

Data presented as \%. *Anti-Saccharomyces cerevisiae (ASCA) antibody panel: ASCA immunoglobulin (Ig) A or ASCA IgG (panel refers to either or both ASCA IgA and IgG positivity); CBir-1 Antibodies to a bacterial flagellin; $C D$ Crohn's disease; 12 Antibodies to a fragment of bacterial DNA associated with Pseudomonas fluorescens; Omp-C Antibodies to the outer membrane porin $C$ of Escherichia coli; pANCA Perinuclear antineutrophil cytoplasmic antibody; RA Rheumatoid arthritis; UC Ulcerative colitis

\section{Assays}

Serum was aliquotted, frozen and shipped to the laboratory of one of the investigators (SRT). Assays were performed for perinuclear antineutrophil cytoplasmic antibody (pANCA), anti-Saccharomyces cerevisiae antibody (ASCA immunoglobulin [Ig]A + IgG and ASCA panel, which was the combined result), antibodies to the outer membrane porin $\mathrm{C}(\mathrm{OmpC})$ of Escherichia coli, antibodies to a fragment of bacterial DNA associated with Pseudomonas fluorescens (I2), which has been cloned from lamina propria mononuclear cells in active Crohn's disease, and to a bacterial flagellin (CBir-1). A T cell line specific for this flagellin induced colitis when transferred into naive severe combined immunodeficient mice. All serum assays were performed in a blinded fashion at Cedars-Sinai Medical Center (California, USA) as described previously (20-24). Antibody levels were determined, with results expressed as ELISA units $(\mathrm{EU} / \mathrm{mL})$, which are relative to Cedars-Sinai Laboratory standards and derived from a pool of patient sera with well-characterized disease found to have reactivity to the specific antigen. ELISA titres (mean \pm SD) were compared among groups using nonparametric tests.

\section{RESULTS}

The average age of the study cohort was 43.4 years, and $66 \%$ were women (Table 1). FN demonstrated a fairly high level of pANCA positivity. While a positive rate of $55 \%$ for FN with ulcerative colitis (in a small sample size $[\mathrm{n}=11]$ ) is within reported ranges for other ulcerative colitis populations, the rate in healthy controls was $32 \%$ and $48 \%$ in RA subjects (Table 2). Even among Caucasians with RA, the pANCA positive rate was $32 \%$. There were comparable rates of Crohn's disease-associated antibodies in the FN and Caucasian populations; however, among FN, up to one in four controls have any one of these antibodies (Table 3). Therefore, although FN experience little IBD, they were relatively responsive to this particular antibody panel.

The ELISA titre values were comparable between groups for any one antibody studied (ie, between ethnic groups and between disease groups), except for pANCA titres, in which FN showed significantly higher pANCA titres in both the ulcerative colitis and RA groups than Caucasians (Table 4).

\section{DISCUSSION}

Because selective antibody expression could differentiate Crohn's disease from ulcerative colitis (ie, ASCA versus pANCA), there was some early enthusiasm that these antibodies might have some pathogenetic significance (25). Furthermore, because bacterial antigens are considered to have an important role in the pathogenesis of Crohn's disease and ulcerative colitis, the potential for an adaptive immune 
response to microbial antigens in the pathogenesis is appealing. It has been shown that ASCA positivity predicted a greater likelihood of complications in pediatric Crohn's disease (26), and has been associated with a more aggressive Crohn's disease phenotype and the need for surgery (27-33). In patients undergoing ileoanal pouch surgery for ulcerative colitis, positivity for pANCA and anti-CBir-1 are associated with a risk for developing pouchitis (34).

While ASCA, anti-CBir-1, anti-OmpC and anti-I2 are positive in approximately $40 \%$ to $50 \%$ of patients with Crohn's disease, and pANCA is positive in approximately $50 \%$ to $75 \%$ of patients with ulcerative colitis $(35,36)$, these antibodies have been reported to be uncommon in healthy controls (37-39). We corroborated these reports for antibodies to OmpC, I2 and Cbir-1 in Manitoba Caucasian and FN populations. However, the rates of ASCA positivity (for the panel) were $14 \%$ to $18 \%$ in controls, and similar for FN and Caucasian populations and, for pANCA, was quite high among FN (32\% in healthy controls).

It was suggested that $\mathrm{FN}$ populations may be genetically programmed to respond differently to certain infections than Caucasians, as evidenced by their differential carriage of single nucleotide polymorphisms for vitamin $\mathrm{D}$ receptor, interferon-gamma, tumour necrosis factor-alpha, monocyte chemoattractant protein 1 and interleukin-6 (40). In fact, the rate of tuberculosis among Canadian FN is much higher than the rate in Canadian-born, non-FN (27.4 per 100,000 population versus two per 100,000 population in 2006) (41). It is, therefore, plausible that FN react differently to microbial antigens with a different antibody response pattern. In our study, this was shown not to be the case because they may respond at an even greater rate to these microbial antigens than Caucasians. In fact, for pANCA, FN had significantly higher mean titres among the ulcerative colitis and RA groups. Unfortunately, a limitation of our study was the small sample size of FN with either Crohn's disease or ulcerative colitis. In fact, the pANCA positivity rate is sufficiently high in non-IBD subjects, which means that this antibody is likely of little diagnostic utility in the FN population. Furthermore, our data suggest that these antibodies are less likely to be pathogenetic because they are equally evident among FN who do not have IBD as in Caucasians.

So why are FN individuals without IBD reacting to pANCA at this rate? pANCA cross-reacts with several commensal bacterial antigens (of which the target antigen resides within the neutrophil [42,43]). In FN populations, this perhaps reflects a generalized increased response to bacteria. FN generally reside in lower socioeconomic areas characterized by crowded living conditions, and Helicobacter pylori infection - as determined by seropositivity - is ubiquitous in some communities $(44,45)$. Mitochondrial DNA, anthropological, archaeological, linguistic, taxonomic and genetic studies (46-51) suggest that Canadian FN are descendants from Central Asia (X2 haplotype) who crossed the Bering Strait 13,000 to 30,000 years previously. Canadian FN, therefore, differ significantly from both Asians and Caucasian subjects with respect to the allelic frequencies of several genes. pANCA
TABLE 3

Percentage positive to any Crohn's disease (CD)-associated antibody or multiple antibody tests

\begin{tabular}{lccc}
\hline & \multicolumn{3}{c}{ CD-associated antibodies, \% } \\
\cline { 2 - 4 } & Any positive & 3 of 4 positive & 4 positive* \\
\hline CD, Caucasian & 70 & 6 & 10 \\
CD, First Nations & 33 & 0 & 0 \\
UC, Caucasian & 32 & 2 & 0 \\
UC, First Nations & 36 & 0 & 0 \\
RA, Caucasian & 26 & 2 & 0 \\
RA, First Nations & 30 & 2 & 0 \\
Controls, Caucasian & 16 & 2 & 0 \\
Controls, First Nations & 24 & 0 & 0 \\
\hline
\end{tabular}

*All of Anti-Saccharomyces cerevisiae antibody panel, fragment of bacterial DNA associated with Pseudomonas fluorescens (I2), outer membrane porin C of Escherichia coli (Omp-C) and bacterial flagellin (CBir-1) are positive. RA Rheumatoid arthritis; UC Ulcerative colitis

and ASCA rates were only $6 \%$ and $4 \%$, respectively, in a sample of normal Chinese subjects (52), and pANCA was only positive in $22 \%$ of a Korean ulcerative colitis population (53). The results of our study suggest that the FN of Manitoba represent an ethnic ancestral population distinct from other populations in which these IBD-associated antibodies have been studied.

\section{CONCLUSION}

The high specificity of these antibodies for IBD and their prevalence in family members $(38,54,55)$ suggest that they are specific to a predilection for IBD in Caucasians. The Crohn's disease-associated antibodies may also be predictive for Crohn's disease within an FN population, although we could not determine this because of the small sample size in our study (but could show that FN with Crohn's disease can be positive for these antibodies). However, the high rates of pANCA positivity in FN without ulcerative colitis and, possibly, the $18 \%$ of FN controls who were ASCA positive suggest that these antibodies are not likely to be of pathogenetic significance.

ACKNOWLEDGEMENTS: This study was supported by a CIHR Team Grant in Arthritis and Inflammatory Bowel Disease. Dr Bernstein is supported, in part, by a Research Investigator Award from the Crohn's and Colitis Foundation of Canada, and the University of Manitoba Bingham Chair in Gastroenterology. He has received consulting fees in the past year from Abbott Canada, AstraZeneca Canada and an unrestricted educational grant from Axcan Pharma. Dr Targan is supported, in part, by reseach grant PPGDK 046763. He is a founder and shareholder of Prometheus Laboratories, USA.

\section{TABLE 4}

\section{Comparison of ELISA titre results*}

\begin{tabular}{|c|c|c|c|c|c|c|}
\hline & pANCA & ASCA IgA & ASCA IgG & 12 & Omp-C & CBir-1 \\
\hline Crohn's disease, Caucasian & $71.2 \pm 20.5$ & $66 \pm 29.7$ & $57.9 \pm 37$ & $51.3 \pm 29.6$ & $50.4 \pm 29.9$ & $46.4 \pm 19.8$ \\
\hline Crohn's disease, First Nations & $54.3 \pm 14.6$ & $71.3 \pm 53.1$ & $100 \pm 42.4$ & 0 & $54.5 \pm 30.4$ & $45.5 \pm 26.2$ \\
\hline Ulcerative colitis, Caucasian & $60 \pm 27$ & $61 \pm 35.4$ & $39.5 \pm 14.7$ & $23.5 \pm 0.7$ & $36.2 \pm 13.6$ & $35 \pm 5.8$ \\
\hline Ulcerative colitis, First Nations & $111.2 \pm 42.5^{\dagger}$ & 34 & $36 \pm 15.6$ & 0 & 27 & $52.3 \pm 42.2$ \\
\hline Rheumatoid arthritis, Caucasian & $48.9 \pm 14.6$ & 25 & $39.7 \pm 29.1$ & 88 & $39 \pm 12.1$ & 30 \\
\hline Rheumatoid arthritis, First Nations & $75.6 \pm 43.7^{\ddagger}$ & 27 & $48.6 \pm 17.5$ & $67 \pm 60.9$ & $46.3 \pm 25.1$ & $28 \pm 4.2$ \\
\hline Control, Caucasian & $45.3 \pm 16.3$ & $48 \pm 13.1$ & $36.2 \pm 22.5$ & 28 & $24 \pm 1.4$ & 31 \\
\hline Control, First Nations & $50.9 \pm 43.3$ & $56 \pm 29.7$ & $33.7 \pm 15.6$ & $36.3 \pm 18.9$ & $33 \pm 8.5$ & 29 \\
\hline
\end{tabular}

${ }^{*}$ Data presented as mean $\pm S D$ ELISA units $/ \mathrm{mL}$. ${ }^{\dagger} P=0.03$ for ulcerative colitis First Nations versus ulcerative colitis Caucasian; ${ }^{\ddagger} P=0.009$ for rheumatoid arthritis First Nations versus rheumatoid arthritis Caucasian. ASCA Anti-Saccharomyces cerevisiae antibody; CBir-1 Antibodies to a bacterial flagellin; 12 Antibodies to a fragment of bacterial DNA associated with Pseudomonas fluorescens; Ig Immunoglobulin; Omp-C Antibodies to the outer membrane porin C of Escherichia coli; pANCA Perinuclear antineutrophil cytoplasmic antibody 


\section{REFERENCES}

1. Bernstein CN, Wajda A, Blanchard JF, et al. The burden of IBD in Canada: A population-based study. Am J Gastroenterol 2006;101:1559-68.

2. Bernstein CN, Blanchard JF, Rawsthorne P, Wajda A. The epidemiology of Crohn's disease and ulcerative colitis in a central Canadian province: A population-based study. Am J Epidemiol 1999;149:916-24.

3. Lowe AM, Roy PO, B-Poulin M, et al. Epidemiology of Crohn's disease in Québec, Canada. Inflamm Bowel Dis 2009;15:429-35.

4. Benchimol EI, Guttman A, Griffiths AM, et al. Increasing incidence of paediatric inflammatory bowel disease in Ontario, Canada: Evidence from health administrative data. Gut 2009;58:1490-7.

5. Blanchard JF, Bernstein CN, Wajda A, Rawsthorne P. Small-area variations and sociodemographic correlates for the incidence of Crohn's disease and ulcerative colitis. Am J Epidemiol 2001;154:328-35.

6. Green C, Elliott L, Beaudoin C, Bernstein CN. An ecological population-based study of IBD: Searching for etiological clues. Am J Epidemiol 2006;164:615-23.

7. Bernstein CN, Shanahan F. Disorders of a modern lifestyle reconciling the epidemiology of inflammatory bowel diseases. Gut 2008; 57:1185-91.

8. Woods RJ, Rothschild BM. Population analysis of symmetrical erosive arthritis in Ohio Woodland Indians (1200 years ago). J Rheumatol 1988;15:1258-63.

9. Rothschild BM, Turner KR, DeLuca MA. Symmetrical erosive peripheral polyarthritis in the late archaic period of Alabama. Science 1988;241:1498-501.

10. Rothschild BM, Woods RJ. Symmetrical erosive disease in Archaic Indians: The origin of rheumatoid arthritis in the New World? Semin Arthritis Rheum 1990;19:278-84.

11. Engel A, Roberts J, Burch TA. Rheumatoid arthritis in adults. Vital Health Stat 1 1966;11:1-43.

12. Linos A, Worthington JW, O'Fallon WM, Kurland LT. The epidemiology of rheumatoid arthritis in Rochester, Minnesota: A study of incidence, prevalence, and mortality. Am J Epidemiol 1980;111:87-98.

13. Harvey J, Lotze M, Stevens MB, et al. Rheumatoid arthritis in a Chippewa Band. I. Pilot screening study of disease prevalence. Arthritis Rheum 1981;24:717-21.

14. Brien WM, Bennett PH, Burch TA, Bunim JJ. A genetic study of rheumatoid arthritis and rheumatoid factor in Blackfeet and Pima Indians. Arthritis Rheum 1967;10:163-79.

15. Willkens RF, Blandau RL, Aoyama DT, Beasley RP. Studies of rheumatoid arthritis among a tribe of Northwest Indians. J Rheumatol 1976;3:9-14.

16. Boyer GS, Templin DW, Lanier AP. Rheumatic diseases in Alaskan Indians of the southeast coast: High prevalence of rheumatoid arthritis and systemic lupus erythematosus. J Rheumatol 1991;18:1477-84.

17. Peschken CA, El-Gabalawy HS, Roos LL, Esdaile JM. Algonkian Indians have twice the frequency of rheumatoid arthritis with a younger age of onset. Arthritis Rheum 1998;41:S558.

18. Sartor RB. Microbial influences in inflammatory bowel diseases. Gastroenterology 2008;134:577-94.

19. Tamboli CP, Neut C, Desreumaux P, Colombel JF. Dysbiosis in inflammatory bowel disease. Gut 2004;53:1-4.

20. Sutton CL, Yang H, Li Z, et al. Familial expression of anti-Saccharomyces cerevisiae mannan antibodies in affected and unaffected relatives of patients with Crohn's disease. Gut 2000;46:58-63.

21. Sutton CL, Kim J, Yamane A, et al. Identification of a novel bacterial sequence associated with Crohn's disease. Gastroenterology 2000;119:23-31.

22. Landers C, Cohavy O, Misra R et al. Selected loss of tolerance evidenced by Crohn's disease-associated immune responses to auto- and microbial antigens. Gastroenterology 2002;123:689-99.

23. Targan SR, Landers CJ, Yang H, et al. Antibodies to CBir1 flagellin define a unique response that is associated independently with complicated Crohn's disease. Gastroenterology 2005;128:2020-8.

24. Lodes MJ, Cong Y, Elson CO, et al. Bacterial flagellin is a dominant antigen in Crohn's disease. J Clin Invest 2004;113:1296-306.

25. Rutgeerts P, Vermeire S. Clinical value of the detection of antibodies in the serum for diagnosis and treatment of inflammatory bowel disease. Gastroenterology 1998;115:1006-8.
26. Amre DK, Lu SE, Costea F, Seidman EG. Utility of serological markers in predicting the early occurrence of complications and surgery in pediatric Crohn's disease patients. Am J Gastroenterol 2006;101:645-52.

27. Ruemmele FM, Targan SR, Levy G, et al. Diagnostic accuracy of serological assays in pediatric inflammatory bowel disease. Gastroenterology 1998;115:822-9.

28. Vasiliauskas, EA, Kam, LY, Karp, LC, et al. Marker antibody expression stratifies Crohn's disease into immunologically homogeneous subgroups with distinct clinical characteristics. Gut 2000;47:487-96.

29. Desir B, Amre DK, Lu SE, et al. Utility of serum antibodies in determining clinical course in pediatric Crohn's disease. Clin Gastroenterol Hepatol 2004;2:139-46.

30. Walker LJ, Aldhous, MC, Drummond, HE, et al. Anti-Saccharomyces cerevisiae antibodies (ASCA) in Crohn's disease are associated with disease severity but not NOD2/CARD15 mutations. Clin Exp Immunol 2004;135:490-6.

31. Mow WS, Vasiliauskas EA, Lin Y-C, et al. Association of antibody responses to microbial antigens and complications of small bowel Crohn's disease. Gastroenterology 2004;126:414-24.

32. Forcione DG, Rosen MJ, Kisiel JB, et al. Anti-Saccaromyces cerevisiae antibody (ASCA) positivity is associated with increased risk for early surgery in Crohn's disease. Gut 2004;53:1117-22.

33. Zholudev A, Zurakowski D, Young W, et al. Serologic testing with ANCA, ASCA, and anti-OmpC in children and young adults with Crohn's disease and ulcerative colitis: Diagnostic value and correlation with disease phenotype. Am J Gastroenterol 2004;99:2235-41.

34. Fleshner P, Ippoliti A, Dubinsky M, et al. Both preoperative perinuclear antineutrophil cytoplasmic antibody and anti-CBir1 expression in ulcerative colitis patients influence pouchitis development after ileal pouch-anal anastomosis.

Clin Gastroenterol Hepatol 2008;6:561-8.

35. Sandborn WJ, Loftus EV Jr, Colombel JF, et al. Evaluation of serologic disease markers in a population-based cohort of patients with ulcerative colitis and Crohn's disease. Inflamm Bowel Dis 2001;7:192-201.

36. Peeters M, Joosens S, Vermeire S, et al. Diagnostic value of anti-Saccharomyces cerivisiae and antineutrophil cytoplasmic autoantibodies in inflammatory bowel disease. Am J Gastroenterol 2001;96:730-4.

37. Duerr RH, Targan SR, Landers CJ, et al. Anti-neutrophil cytoplasmic antibodies in ulcerative colitis. Comparison with other colitides/diarrheal illnesses. Gastroenterology 1991;100:1590-6.

38. Annese V, Andreoli A, Andriulli A, et al. Familial expression of anti-Saccharomyces cerevisiae Mannan antibodies in Crohn's disease and ulcerative colitis: A GISC study. Am J Gastroenterol 2001;96:2407-12.

39. Quinton JF, Sendid B, Reumaux D, et al. Anti-Saccharomyces cerevisiae mannan antibodies combined with antineutrophil cytoplasmic autoantibodies in inflammatory bowel disease: Prevalence and diagnostic role. Gut 1998;42:788-91.

40. Larcombe L, Rempel JD, Dembinsli I, et al. Differential cytokine genotype frequencies among Canadian Aboriginal and Caucasian populations. Genes Immunity 2005;6:140-4.

41. Larcombe LA, Orr PH, Lodge AM, et al. Functional gene polymorphisms in Canadian Aboriginal populations with high rates of tuberculosis. J Infect Dis 2008;198:1175-9.

42. Seibold F, Brandwein S, Simpson S, et al. pANCA represents a cross-reactivity to enteric bacterial antigens. J Clin Immunol 1998;18:153-8.

43. Eggena M, Cohavy $\mathrm{O}$, Parseghian $\mathrm{MH}$, et al. Identification of histone $\mathrm{H} 1$ as a cognate antigen of the ulcerative colitis-associated marker antibody pANCA. J Autoimmun 2000;14:83-97.

44. Bernstein CN, Mckeown I, Embil JM, et al. Seroprevalence of Helicobacter pylori, and incidence of gastric cancer and peptic ulcer associated hospitalizations, in a Canadian Indian population. Dig Dis Sci 1999;44:668-74.

45. Sinha SK, Martin B, Gold BD, et al. The incidence of Helicobacter pylori acquisition in children of a Canadian First Nations community: And the potential for parent-to-child-transmission. Helicobacter 2004;9:59-68.

46. Schanfield MS. Immunoglobulin allotypes indicate multiple founding populations of Native Americans: Evidence of at least four migrations to the New World. Hum Biol 1992;64:381-402. 
47. Weiss KM. American origins. Proc Natl Acad Sci USA 1994;91:833-5.

48. Torroni A, Neel JV, Barrantes R, Schurr TG, Wallace DC. Mitochondrial DNA "clock" for the Amerinds and its implications for timing their entry into North America. Proc Natl Acad Sci USA 1994;91:1158-62.

49. Nowak MP, Tyndale RF, Sellers EM. CYP2D6 phenotype and genotype in a Canadian Native Indian population. Pharmacogenetics 1997;7:145-8.

50. Nowak MP, Sellers EM, Tyndale RF. Canadian Native Indians exhibit unique CYP2A6 and CYP2C19 mutant allele frequencies. Clin Pharmacol Ther 1998;64:378-83.

51. Brown MD, Hosseini SH, Torroni A, et al. mtDNA haplogroup X: An ancient link between Europe/Western Asia and North America? Am J Hum Genet 1998;63:1852-61.
52. Lawrance IC, Murray K, Hall A, Sung JJ, Leong R. A prospective comparative study of ASCA and pANCA in Chinese and Caucasian IBD patients. Am J Gastroenterol 2004;99:2186-94.

53. Lee JH, Cheon JH, Kim ES, et al. The prevalence and clinical significance of perinuclear anti-neutrophil cytoplasmic antibody in Korean patients with ulcerative colitis. Dig Dis Sci 2010;55:1406-12.

54. Vermeire S, Peeters M, Vlietinck R et al. Anti-Saccharomyces cerivisiae antibodies (ASCA), phenotypes of IBD, and intestinal permeability: A study in IBD families. Inflamm Bowel Dis 2001;7:8-15.

55. Ling M, Targan SR, Landers CJ, et al. Familial expression of anti Escherichia coli outer membrane porin $\mathrm{C}$ in relatives of patients with Crohn's disease. Gastroenterology 2006;130:1076-85. 


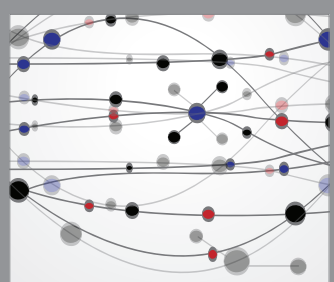

The Scientific World Journal
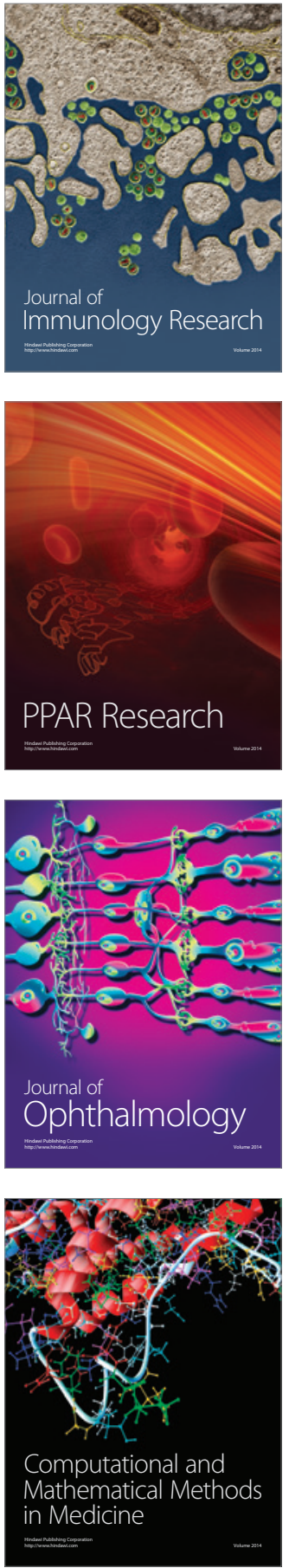

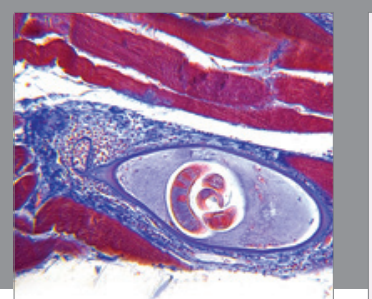

Gastroenterology Research and Practice

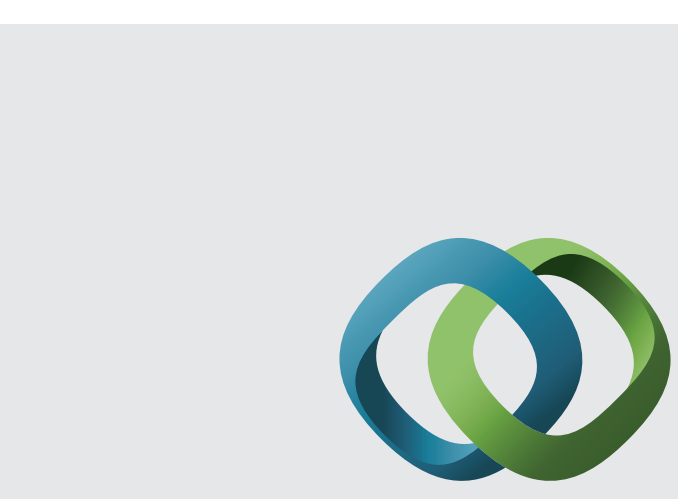

\section{Hindawi}

Submit your manuscripts at

http://www.hindawi.com
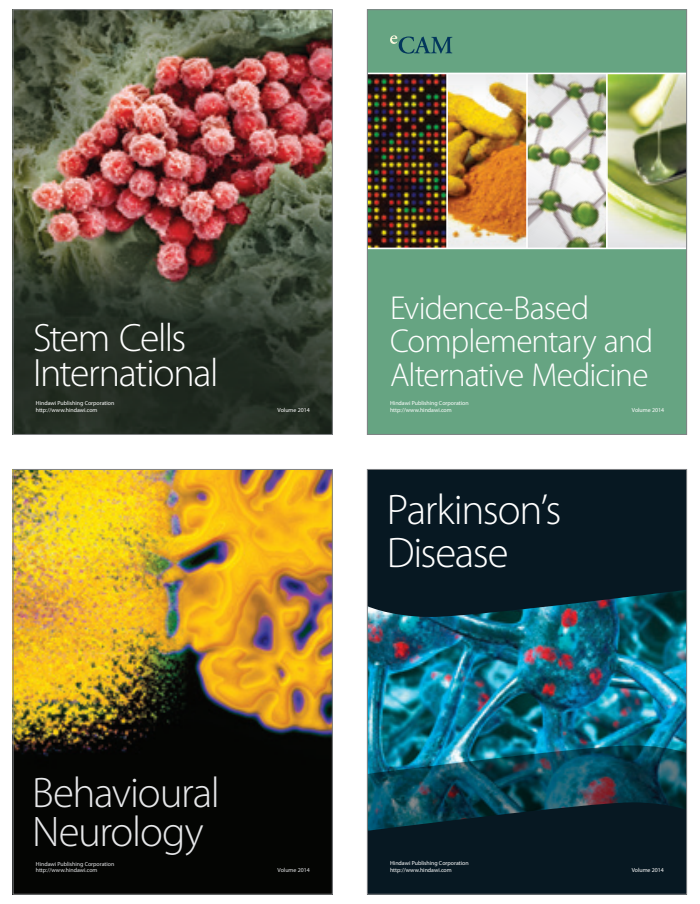
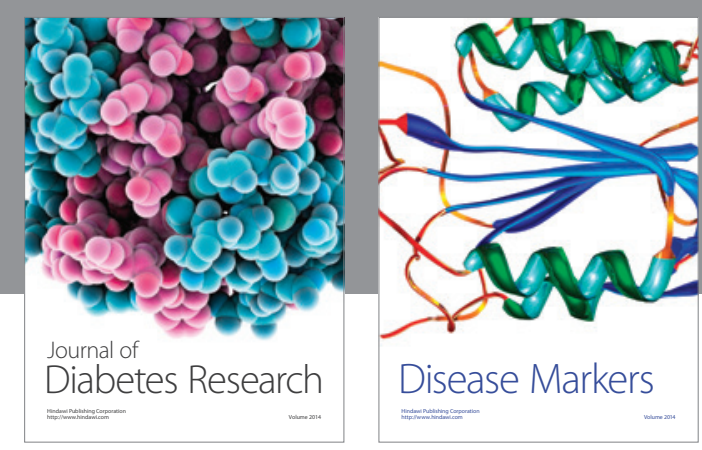

Disease Markers
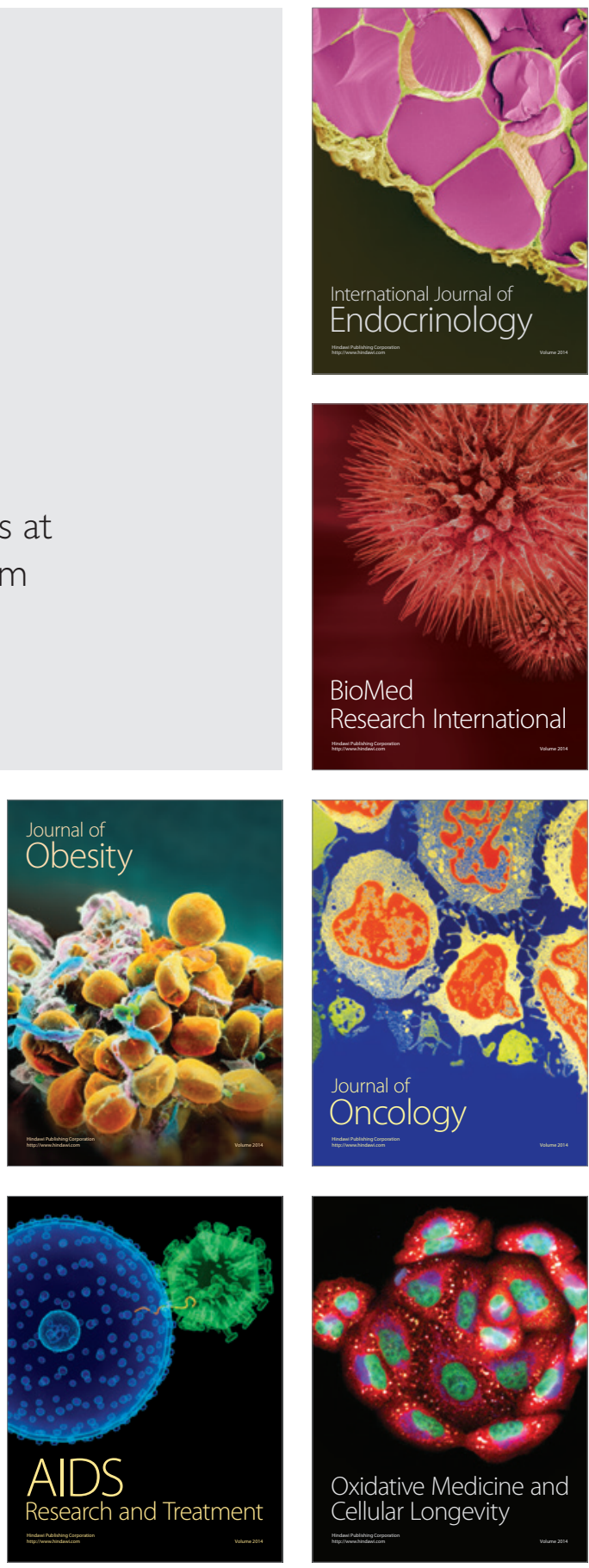